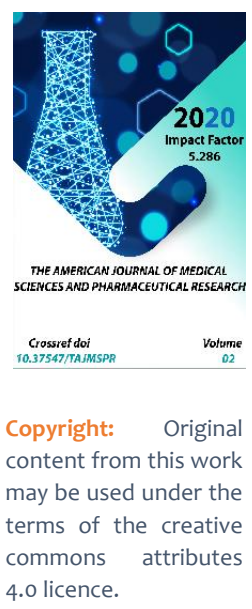

\title{
Indications And Causes Of Helminthosis In Children (On Materials Of Surkhandarya Region)
}

\author{
Jamshed Jafarovich Jalilov \\ Lecturer In Valeology, Termez State University, Uzbekistan \\ Masuma Umarovna Raxmatova \\ Senior Lecturer At Termez State University, Uzbekistan \\ Sarvinoz Anvarovna Khudoyberdieva \\ Student - Bachelor Of 3 Courses Faculty Of Biology, Termez State University, Uzbekistan \\ Zafar Zokirovich Aliev \\ Student - Bachelor Of 3 Courses Faculty Of Biology, Termez State University, Uzbekistan
}

\section{ABSTRACT}

This article presents information and conclusions about helminths in children in Surkhandarya region of Uzbekistan. According to the research results, in Surkhandarya province $44 \%$ of children are infected with enterobiasis and $23 \%$ with ascariasis, and the reasons for this are explained.

\section{KEYWORDS}

Children's helminthosis, healthy lifestyle, children's disability, acquired disability, pathogens weaken.

\section{INTRODUCTION}

Helminthiasis is one of the most common diseases in the world, accounting for a significant proportion of common diseases and having a negative impact on the socioeconomic indicators of society. Even though $80 \%$ of cases are registered among children, it remains a constant problem among the population at this age. Pathogens weaken children's immune system and cause the development of various allergic diseases, including dermatitis, asthmatic bronchitis, rhinitis and metabolic disorders, various intestinal diseases, physical and mental weakness and many other diseases, as well as 
acquired disorders. It should be noted that children have high morbidity rates due to close contact with contaminated toys, household appliances and external environmental factors (soil, open water pool).

Currently, the incidence of enterobiasis (ostrich), hymenolepidosis (tapeworm), and ascariasis (ascarida) in children is $80 \%$ higher than in other types of helminths. In children's institutions, this figure is $90 \%$. In particular, in Surkhandarya region, in kindergartens located in Termez, Denau, Shurchi, Altynsay, Boysun, Jarkurgan and Termez districts, disinfection of children's toys is not at the necessary level, so helminthiasis is more common among children of child age. Percentage of children with helminthiasis in these districts and town of Termez is increasing day by day and number of children with disabilities is increasing.

\section{THE AIM OF THE RESEARCH}

To scientifically substantiate the indicators and causes of helminth diseases in children in Surkhandarya region (by the example of individual districts).

\section{RESEARCH MATERIAL AND METHODS}

Sanitary and demographic indicators of Surkhandarya region, data on children's health, medical services for population of separate districts, statistics on condition of population of Surkhandarya region The causes of helminthiasis in children were studied.

The cities of Termez, Denau, Shurchi, Altynsay, Boysun, Jarkurgan and Termez in Surkhandarya province were exposed to helminthiasis using the "incident monitoring" research method. Healthy children (300 children) were included in the control group, children with helminthosis (300 children) were included in the incident group and the study was based on these groups and we studied the study in 4 stages. According to statistics, as of December 31, 2019 in Surkhandarya region there are 13 districts and 1 city in which $83.4 \%$ of children registered with enterobiasis, ascariasis, hymenolepidosis at children aged till 14 years live in Termez, Denau, Shurchi, Altynsay, Boysun, Jarkurgan and Termez districts (Table 1).

Table-1

Index of helminthiasis in children of Surkhandarya region for 2018-2019 (per 300 children)

\begin{tabular}{|c|c|c|c|c|}
\hline \multirow{2}{*}{ Districts and cities } & \multicolumn{2}{|c|}{ Total } & \multicolumn{2}{c|}{ per 300 children (\%) } \\
\cline { 2 - 5 } & $\mathbf{2 0 1 8}$ й & $\mathbf{2 0 1 9}$ й & $\mathbf{2 0 1 8}$ й & 2019 й \\
\hline Termez city & 574 & 596 & 6,5 & 7,0 \\
\hline Altynsay & 556 & 581 & 7,9 & 8,4 \\
\hline Angor & 444 & 450 & 6,6 & 6,7 \\
\hline Muzrabot & 450 & 511 & 6,7 & 7,3 \\
\hline Sherobod & 419 & 437 & 6,6 & 6,8 \\
\hline
\end{tabular}


The American Journal of Medical Sciences and Pharmaceutical Research (ISSN - 2689-1026)

Published: October 30, 2020 | Pages: 76-81

Doi: https://doi.org/10.37547/TAJMSPR/Volumeo2Issue10-12

\begin{tabular}{|c|c|c|c|c|}
\hline Boysun & 548 & 561 & 6,0 & 6,7 \\
\hline Kumkurgan & 419 & 437 & 6,6 & 6,8 \\
\hline Jarkurgan & 626 & 686 & 7,5 & 7,9 \\
\hline Shurchi & 685 & 777 & 7,0 & 8,9 \\
\hline Kizirik & 456 & 491 & 5,5 & 6,3 \\
\hline Termez district & 611 & 626 & 7,3 & 7,5 \\
\hline Sariosiyo & 341 & 369 & 5,7 & 6,7 \\
\hline Denau & 1227 & 1242 & 8,1 & 8,6 \\
\hline Uzun & 338 & 363 & 6,6 & 7,0 \\
\hline By region: & 7694 & 8127 & 6,8 & 7,3 \\
\hline
\end{tabular}

According to Table 1, if we look at the dynamics of helminths in children in the Surkhandarya region in 2018-2019, we can see a trend of increasing helminths in children. The helminth disease incidence in children increased slightly compared to 2018, including $6.8 \%$ by 300 children in 2018 and $7.3 \%$ by 2019.

The following helminths are the main causes of helminthiasis in children:

Askarid - when playing in the mud, leaving the street, do not wash your hands thoroughly with soap before eating and after going to the toilet, do not make sure to litter a person (often do not wash the toilet seats), use a few children without disinfected toys, do not wash fruits and vegetables completely (without cleaning or in raw form) when eating nails are not removed often, personal hygiene rules are not observed;

Striped worms - from well cooked or raw meat (worm eggs to pork, beef and fish);

Oysters may spread through toilet seats or when hygiene is not practiced, and when a person with oysters breathes, ostrich eggs are thrown into the air while breathing.

According to our study, enterobiasis in children under 14 years old in Surkhandarya region in 2018-2019 is $11.7 \%$ in Denau district, $10.9 \%$ in Jarkurgan district, 9.5\% in Shurchi district, 9.1\% in Boysun district, $8.9 \%$ in Sherabad district, $8.6 \%$ in Altynsay district, $8.1 \%$ in Termez district and $33.2 \%$ in other districts 
(Figure 1).

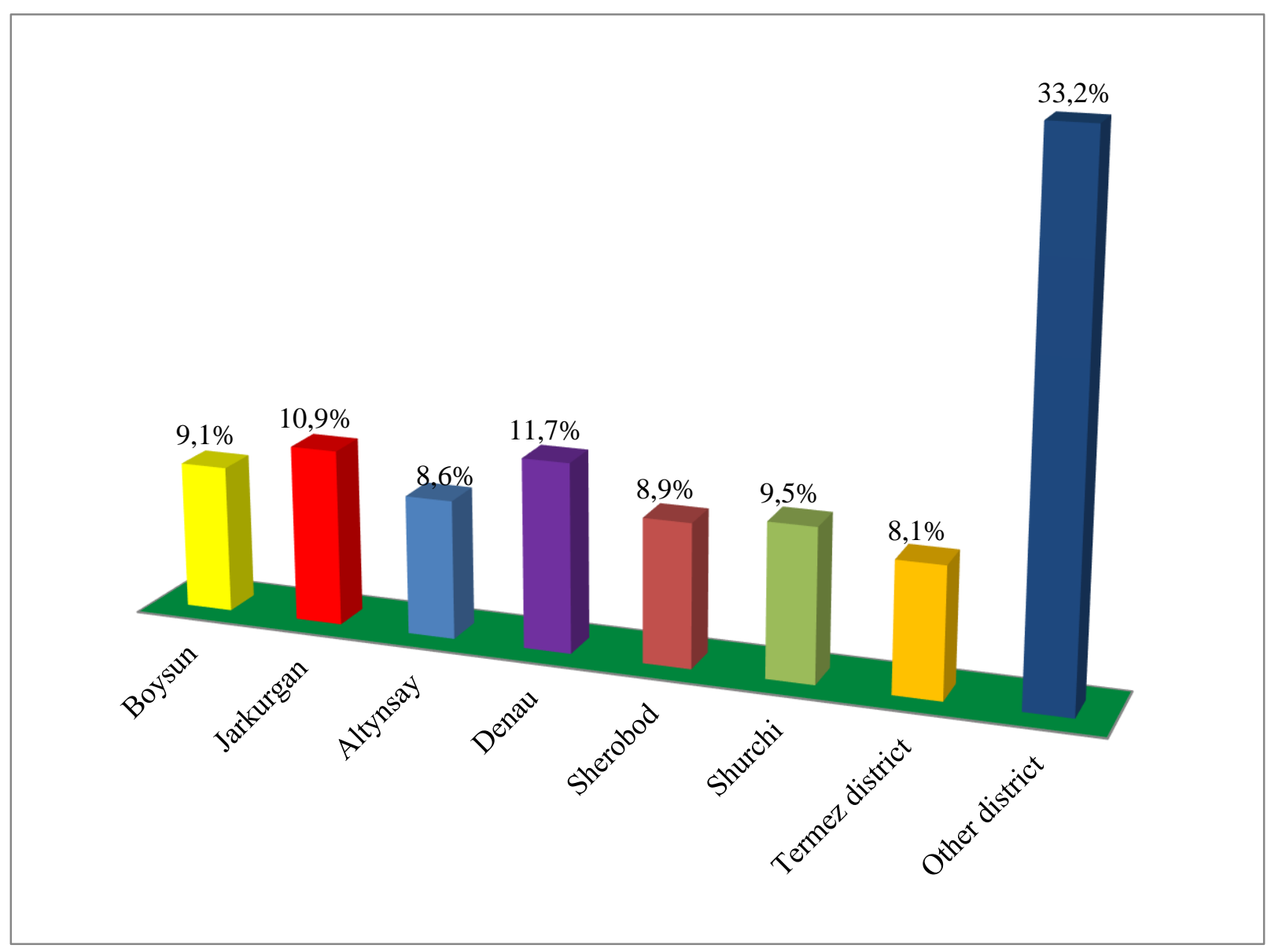

Figure 1:The prevalence rate of enterobiasis in children under 14 years of age.

The prevalence of ascaridosis by sex was $50.7 \%$ among boys in 2018, 49.3\% among girls, 51\% among boys in 2019, 49\% among girls, 50.8\% among boys in 2020 and $49.2 \%$ among girls. (Table 2).

Table-2

Gender prevalence of ascaridosis in children under 14 years of age in Surkhandarya region in 2018-2020. (As of 1 May 2020)

\begin{tabular}{|c|c|c|c|c|c|c|}
\hline \multirow{2}{*}{$\begin{array}{c}\text { At the intersection } \\
\text { of cities and districts }\end{array}$} & \multicolumn{2}{|c|}{$2018(\%)$} & \multicolumn{2}{c|}{$2019(\%)$} & \multicolumn{2}{c|}{$2020(\%)$} \\
\cline { 2 - 7 } & boys & girls & boys & girls & boys & girls \\
\hline Termez city & 61,5 & 38,5 & 59,4 & 40,6 & 51,9 & 48,1 \\
\hline
\end{tabular}


The American Journal of Medical Sciences and Pharmaceutical Research (ISSN - 2689-1026)

Published: October 30, 2020 | Pages: 76-81

Doi: https://doi.org/10.37547/TAJMSPR/Volumeo2Issue10-12

\begin{tabular}{|c|c|c|c|c|c|c|}
\hline \multirow{2}{*}{ Altynsay } & 51,2 & 48,8 & 51,7 & 48,3 & 50,6 & 49,4 \\
\hline Angor & 55,2 & 44,8 & 57,4 & 42,6 & 56,5 & 43,5 \\
\hline Muzrabot & 41,8 & 58,2 & 41,3 & 58,7 & 44,7 & 55,3 \\
\hline Sherobod & 50,4 & 49,6 & 50,8 & 49,2 & 49,7 & 50,3 \\
\hline Boysun & 50,8 & 49,2 & 51,1 & 48,9 & 51,7 & 48,3 \\
\hline Kumkurgan & 50,2 & 49,8 & 50,4 & 49,6 & 50,8 & 49,2 \\
\hline Jarkurgan & 49,2 & 50,8 & 50,7 & 49,3 & 50,9 & 49,1 \\
\hline Shurchi & 50,3 & 49,7 & 50,5 & 49,5 & 51,2 & 48,8 \\
\hline Kizirik & 49,2 & 50,8 & 50,1 & 49,9 & 49,1 & 50,9 \\
\hline Termez district & 46,4 & 53,6 & 47,2 & 52,8 & 47,8 & 52,2 \\
\hline Sariosiyo & 52,9 & 47,1 & 53,6 & 46,4 & 54,3 & 45,7 \\
\hline Denau & 50,4 & 49,6 & 50,1 & 49,9 & 51,4 & 48,6 \\
\hline Uzun & 50,7 & 49,3 & 50,1 & 49,9 & 51,3 & 48,7 \\
\hline By region: & 50,7 & 49,3 & 51 & 49 & 50,8 & 49,2 \\
\hline
\end{tabular}

This table shows that the prevalence of ascaridosis by sex is slightly higher in boys than in girls.

\section{CONCLUSION}

According to our study, the incidence of enterobiasis in children in Surkhandarya region is $44 \%$ and that of ascariasis is $23 \%$, which is the main cause of helminthiasis. Among all infected helminthoses, $78.9 \%$ of cases of enterobiasis in children, $71 \%$ of cases of ascaridosis, $69.7 \%$ of ostrich, $58.5 \%$ of hymenolepidosis and $55 \%$ of hyardiasis in children.

Studies have shown that the most important requirement in the fight against helminthiasis is the prevention and choice of the right and effective medicines. In order to understand which drugs to use, it is necessary to undergo a thorough examination, determine the stage of the disease and only then begin treatment. During the prophylaxis, it is necessary to monitor the sanitary condition of living, working and training areas. Fish and meat 
should be well roasted, as they may contain helminths. Immunity measures should be taken. Effective treatment is not possible without proper understanding of adaptation mechanisms.

\section{REFERENCES}

1. Sanitary epidemiological Surkhandarya region peace center report for 2017-2020.

2. Myandina I.G., Tarasenko V.E. Medical parasitology. Practical Medicine - 2013. $280 \mathrm{p}$.

3. Medical parasitology; Medicine-Moscow, 2012. - 304 p.

4. Kornakova EE. Medical parasitology. M.: Academy, 2010. - 34 p.

5. Jalilov J. J. The role of medical workers and scringing centers in preventing the birth of children with disabilities in the Surkhandarya region; International scientific journal; New day in medicine 2019. $-28-32 \mathrm{p}$. 